\title{
The response of laying hens fed fermented pineapple peel waste by indigenous microorganism from bamboo sprout
}

\section{Resposta de galinhas poedeiras alimentadas com residuos fermentados de casca de abacaxi por microorganismos indígenas do broto de bambu}

\author{
YAN, Heryandi ${ }^{1 *}$ \\ https://orcid.org/0000-0002-6095-0337 \\ NOVA, Putri Yanti \\ https://orcid.org/0000-0001-6547-8847
}

\author{
ADRIZAL ${ }^{2}$, Adrizal \\ https://orcid.org/0000-0002-0923-7691 \\ MAHATA, Maria Endo 2* \\ https://orcid.org/0000-0002-4692-9806
}

\footnotetext{
${ }^{1}$ Universitas Andalas, Departamento de Produção Animal, Faculdade de Ciências Animais, Limau Manis, Pauh, Padang City, 25163, Indonesia

${ }^{2}$ Universitas Andalas, Departamento de Nutrição e Tecnologia de Alimentos, Faculdade de Ciências Animais, Limau Manis, Pauh, Padang City, 25163, Indonesia

*Mail for correspondence: maria@ansci.unand.ac.id
}

\begin{abstract}
The bromelain enzyme content in pineapple peel waste predicted to promote digestive tract health and a positive effect on egg quality. This research aimed to evaluate the use of fermented pineapple peel waste in laying hens diet on egg quality. A total of laying hens 200 birds with Isa Brown strain, egg production of $70 \%$, The average egg weight and body weight were $58.58 \mathrm{~g} / \mathrm{egg}$, and $1.62 \mathrm{~g} / \mathrm{bird}$, respectively. A completely randomized design was used, 5 different levels of fermented pineapple peel waste as treatment $(0,5,10,15$, and $20 \%)$, and all treatments were repeated 4 times. Egg shell thickness, egg shell strength, haugh unit, egg yolk fat, and egg yolk color were measured. The use of fermented pineapple peel waste in the diet of laying hens up to $20 \%$ highly significant $(\mathrm{P}<0.01)$ on egg yolk color, and did not negative effect $(\mathrm{P}>0.05)$ on egg shell thickness, egg shell strength, haugh unit, and egg yolk fat. Fermented pineapple peel waste can be used as much as $20 \%$ in laying hens diet without disturbing egg quality and improve egg yolk color.
\end{abstract}

Key words: egg quality, indigenous microorganism, laying hens, pineapple peel waste, egg yolk color

\section{RESUMO}

O conteúdo da enzima bromelina nos resíduos de casca de abacaxi previa promover a saúde do trato digestivo e um efeito positivo na qualidade dos ovos. Esta pesquisa teve como objetivo avaliar o uso de resíduos de casca de abacaxi fermentado na dieta de galinhas poedeiras, investigando seu efeito na qualidade dos ovos. Um total de galinhas poedeiras 200 aves com cepa Isa Brown, 70\% de produção de ovos. O peso médio dos 
ovos e o peso corporal foram 58,58 g / ovo e 1,62 g / ave, respectivamente. Utilizou-se um delineamento inteiramente casualizado, com 5 níveis diferentes de resíduos de casca de abacaxi fermentado como tratamento $(0,5,10,15$ e $20 \%)$ e todos os tratamentos foram repetidos 4 vezes. A espessura da casca do ovo, a força da casca do ovo, a unidade de haugh, a gordura da gema do ovo e a cor da gema do ovo foram medidas. O uso de resíduos de casca de abacaxi fermentado na dieta de galinhas poedeiras de até $20 \%$ de alta significância $(\mathrm{P}<0,01)$ na cor da gema de ovo e não teve efeito negativo $(\mathrm{P}>0,05)$ na espessura da casca do ovo, na força da casca do ovo, na unidade de haugh e gordura de gema de ovo. O desperdício fermentado de casca de abacaxi pode ser usado em até $20 \%$ na dieta de galinhas poedeiras, sem prejudicar a qualidade dos ovos e melhorar a cor da gema.

Palavras-chave: qualidade dos ovos, microrganismo indígena, galinhas poedeiras, desperdício de casca de abacaxi, cor da gema

\section{INTRODUCTION}

Pineapple production in Indonesia from year to year always increases. Pineapple production in 2017 reached 1.795,986 tons and in 2018 increased to 1.805,506 tons (Indonesia Central Bureau of Statistic, 2017 and 2018), and 30\% from pineapple fresh is pineapple peel waste (Campos et al., 2020). The high availability of pineapple peel waste in Indonesia is an opportunity to be used as laying hens feed.

Pineapple peel waste contains $24.00 \%$ crude fiber (Mahata et al., 2016), It's hard to digest by laying hens because their digestive tract produces limited cellulase enzyme to degrade crude fiber. Fermentation of pineapple peel waste by indigenous microorganisms solution from bamboo sprouts anaerobically reduced $28.5 \%$ crude fiber, and contain $12.85 \%$ water, $87.15 \%$ dry matter, $8.95 \%$ crude protein, $2.08 \%$ crude fat, $\mathrm{Ca}$ $0,16 \%, \mathrm{P} 0.38 \%$, and metabolized energy $1190.47 \mathrm{kcal} / \mathrm{kg}$ (Adrizal et al., 2017). Some indigenous microorganism in bamboo sprouts are cellulolytic bacteria such as Bacillus thuringiensis, Bacillus aerus, and Lactobacillus plantarum, and cellulolytic fungi Panus velutinus, which were produced cellulase enzymes to degrade crude fiber in pineapple peel waste (Mahata, 2019).

Fermented pineapple peel waste contains $0.032 \mathrm{U} / \mathrm{ml}$ bromelain enzyme activity (Laboratory analysis of Feed Industry Technology, Andalas University, 2017). Bromelain enzymes hydrolysis protein to peptides and improve the digestion of proteins in the digestive tract of poultry (Manosroi et al., 2014; Swan and Nagendran, 2014).

Lien et al. (2012), reported the inclusion of bromelain as much as $0.28 \mathrm{~g} / \mathrm{kg}$ feed increased the egg shell thickness of laying hens, while Yenice et al. (2019) stated the inclusion of bromelain enzymes of $0.45 \mathrm{~g} / \mathrm{kg}$ feed increased egg shell thickness and haugh units of laying hens. Besides that, pineapple contains carotenoid as much as $497 \mu \mathrm{g} / 100 \mathrm{~g}$, and vitamin $\mathrm{C}$ is $38.3 \mathrm{mg} / 100 \mathrm{~g}$ (Ellong et al., 2015), Carotenoids was expected increase the color of egg yolk, and vitamin $\mathrm{C}$ is useful for the health of laying hens. Mandey et al. (2017) reported pineapple peel waste fermented by 'yeast tape' can be used in broiler rations as much as $20 \%$. So far, there is no research reporting about of fermented pineapple peel waste with local microorganisms from bamboo sprout for laying hens diet. This research aimed to 
evaluate the use of fermented pineapple peel waste in laying hens diet on egg quality.

\section{MATERIALS AND METHODS}

Experimental chicken: Livestock used were 200 laying hens of ISA Brown strain, with average body weight was $1.62 \mathrm{~g} / \mathrm{bird}$, egg weight $58.58 \mathrm{~g} / \mathrm{egg}$, and egg production $70 \%$.

The procedure of FPPW: Prepare pineapple peel waste, cleaned, and mashed. Then weighed as much as $500 \mathrm{~g}$ and put in a fermentor. Added $325 \mathrm{ml}$ of indigenous microorganisms from bamboo sprouts and mixed until homogeneous. Furthermore, it was incubated for one week. After one week, the incubation process was stopped, and the fermented product was dried in the sun. Fermented products were ready to be used as poultry feed ingredients.

Diet: The experimental diet was prepared iso-protein $(16 \%)$, and iso-energy $(2600$ $\mathrm{kcal} / \mathrm{kg}$ ). Top mix, palm oil, flour stone, cargil concentrate, rice bran, yellow corn, and FPPW were the ingredients used, show in Table 1.

Table 1. Experimental feed composition, nutrient content (\%), and energy metabolism (kcal/kg)

\begin{tabular}{|c|c|c|c|c|c|}
\hline \multirow{2}{*}{ Feedstuffs $(\%)$} & \multicolumn{5}{|c|}{ Experimental diets of fermented pineapple peel waste (\%) } \\
\hline & 0 & 5 & 10 & 15 & 20 \\
\hline $\begin{array}{l}{ }^{*} \text { Concentrate } \\
\text { commercial for laying } \\
\text { hens }\end{array}$ & 28.00 & 28.00 & 28.00 & 28.00 & 28.00 \\
\hline Yellow corn & 44.00 & 43.00 & 42.00 & 41.00 & 40.00 \\
\hline Rice bran & 23.00 & 18.75 & 14.50 & 10.25 & 6.00 \\
\hline Palm oil & 0.25 & 0.75 & 1.25 & 1.75 & 2.25 \\
\hline${ }^{* *}$ Commercial top mix & 0.50 & 0.50 & 0.50 & 0.50 & 0.50 \\
\hline Flour stone & 4.25 & 4.00 & 3.75 & 3.50 & 3.25 \\
\hline FPPW & 0.00 & 5.00 & 10.00 & 15.00 & 20.00 \\
\hline Total & 100.00 & 100.00 & 100.00 & 100.00 & 100.00 \\
\hline \multicolumn{6}{|c|}{ Counts of feed substances $(\%)$ and energy metabolism } \\
\hline Crude protein $(\%)$ & 16.48 & 16.37 & 16.27 & 16.16 & 16.05 \\
\hline Crude fiber $(\%)$ & 5.80 & 6.11 & 6.41 & 6.72 & 7.02 \\
\hline Crude fat $(\%)$ & 3.93 & 4.23 & 4.53 & 4.59 & 5.12 \\
\hline Calcium (\%) & 3.47 & 3.42 & 3.37 & 3.33 & 3.28 \\
\hline $\begin{array}{l}\text { availability of } \\
\text { phosphorus (\%) }\end{array}$ & 0.26 & 0.27 & 0.28 & 0.28 & 0.29 \\
\hline $\begin{array}{l}\text { Energy metabolism } \\
(\mathrm{kcal} / \mathrm{kg})\end{array}$ & 2623.92 & 2623.77 & 2623.62 & 2623.47 & 2623.32 \\
\hline Methionine (\%) & 0.15 & 0.14 & 0.13 & 0.11 & 0.10 \\
\hline Lysin $(\%)$ & 0.22 & 0.20 & 0.17 & 0.14 & 0.12 \\
\hline
\end{tabular}

${ }^{*}$ Concentrate commercial for laying hens produced by feed industry in Indonesia named Cargill. Commercial concentrate nutritional compotition is $12 \%$ maximum moisture, $17-19 \%$ crude protein, $3 \%$ minimum crude fat, $7 \%$ maximum crude fiber, $14 \%$ maximum ash, $3.25-4.25 \%$ calcium, 0.45 minimum phosphorus, and $50 \mathrm{ppb}$ of maximum antioxidants. 
${ }^{* *}$ Commercial top mix produced by feed industry in Indonesia named Medion. Commercial top mix composition for each $10 \mathrm{~kg}$ contain: $12.000 .000 \mathrm{IU}$ vitamin $\mathrm{A}, 2.000 .000 \mathrm{IU}$ vitamin $\mathrm{D}_{3}, 8.000$ IU vitamin $\mathrm{E}, 2.000 \mathrm{mg}$ vitamin $\mathrm{K}_{3}, 2.000 \mathrm{mg}$ vitamin $\mathrm{B}_{1}, 5.000 \mathrm{mg}$ vitamin $\mathrm{B}_{2}, 500 \mathrm{mg}$ vitamin $\mathrm{B}_{6}, 12.000 \mu \mathrm{g}$ vitamin $\mathrm{B}_{12}, 25.000 \mathrm{mg}$ vitamin $\mathrm{C}, 6.000 \mathrm{mg}$ Calcium-D-pantothenate, 40.000 niacin, $10.000 \mathrm{mg}$ cholin chloride, $30.000 \mathrm{mg}$ methionine, $30.000 \mathrm{mg}$ lysine, $120.000 \mathrm{mg}$ manganese, $20.000 \mathrm{mg}$ iron, $200 \mathrm{mg}$ iodine, $100.000 \mathrm{mg}$ zinc, $200 \mathrm{mg}$ cobalt, $4.000 \mathrm{mg}$ copper, $10.000 \mathrm{mg}$ santoquin (antioxidant), 1.300.000 mg growth promoter.

Study design: The study was performed in a completely randomized design with five treatments $(0,5,10,15$, and 20\% FPPW as treatments), all treatment was repeated four times with ten birds for each repetition, and egg quality evaluation was used forty eggs for each treatment. Egg shell thickness: The eggshell thickness was measured in three parts, namely the equator, the air bag, and the tip of the egg section, furthermore data from the three sections were averaged to get the egg shell thickness (Aydin et al., 2008). The instrument used was a screw micrometer.

Egg shell strength: Eggshell strength was measured by using the Egg Force Reader equipment (SHIMPO FGV-10XY).

Haugh unit: Haugh unit was measured by Haugh (1937), method. Egg was weighed by using a digital scale, then it broken and placed on a flat glass. Futhermore, the height albumen was measured by a caliper.

Egg yolk fat: Egg yolk fat was measured by using the method described by AOAC (2005). The egg yolk sample was weighed $1 \mathrm{~g}$, then wrapped by using grease paper, then dried in an oven at temperature of $105-110^{\circ} \mathrm{C}$. Furthermore, the sample was extracted with diethyl ether using Soxhlet until the liquid was clear. The extraction was stopped, and the sample was aerated to dry, then drying in an oven for 6 hours at temperature of $105-110^{\circ} \mathrm{C}$. Furthermore all samples were put into a desiccator for
15 minutes, after which the samples were weighed.

Egg yolk color: The egg yolk color assessment was carried out involving 20 panelists by comparing the egg yolk color using the egg yolk color fan tool has a Roche scale, which is a standard color of 1-15 from pale to deep colors.

Fermented pineapple peel waste preparetion: Fermented pineapple peel waste was conducted by weighed $500 \mathrm{~g}$ of fresh pineapple peel waste and mixing it with $325 \mathrm{~mL}$ of local microorganism solution from bamboo sprouts. Furthermore, incubated for one week (Adrizal et al., 2017)

Statistical analysis: Data was achieved by using the variance analysis with a completely randomized design, and using duncan's multiple range test if there were differences between treatments (Steel and Torrie, 1995).

\section{RESULTS AND DISUSSION}

Analysis of the egg shell thickness, egg shell strength, haugh unit, egg yolk fat, and egg yolk color data are shown in Table 2. Inclusion of FPPW caused no significant decrease in egg shell thickness, egg shell strength, haugh unit, and egg yolk fat $(\mathrm{P}>0.05)$. FPPW in a diet of laying hens does not interfere with the egg shell thickness and egg shell strength. Administration using five levels of FPPW does not reduce the phosphorus availability and calcium content in a diet of the laying hens. It predicted the local 
microorganism solution produced phytase for degrading phytate in pineapple peel waste when fermentation process to release phosphorus and calcium, therefore both of them were available for laying hens.

Table 2. The average from egg shell thickness, egg shell strength, haugh unit, egg yolk fat, and egg yolk color of laying hens fed treatments diet

\begin{tabular}{|c|c|c|c|c|c|c|}
\hline \multirow[b]{2}{*}{ Parameters } & \multicolumn{5}{|c|}{ Treatments (FPPW \%) } & \multirow[b]{2}{*}{ SE } \\
\hline & A. 0 & B. 5 & $\begin{array}{c}\text { C. } 1 \\
0\end{array}$ & $\begin{array}{c}\text { D. } 1 \\
5\end{array}$ & $\begin{array}{c}\text { E. } 2 \\
0\end{array}$ & \\
\hline Egg shell thickness (mm) & 0.44 & 0.43 & 0.45 & 0.43 & 0.43 & 0.01 \\
\hline $\begin{array}{l}\text { Egg shell strength } \\
\left(\mathrm{kg} / \mathrm{cm}^{2}\right)\end{array}$ & 3.45 & 4.20 & 4.32 & 4.75 & 3.85 & 0.06 \\
\hline Haugh unit & 95.0 & 93.8 & 93.2 & 93.8 & 98.0 & 2.60 \\
\hline Egg yolk fat (\%) & 30.51 & 30.39 & 29.57 & 29.13 & 28.63 & 0.47 \\
\hline Egg yolk color & $8.49^{c}$ & $8.70^{\mathrm{bc}}$ & $9.06^{\mathrm{abc}}$ & $9.26^{\mathrm{ab}}$ & $9.41^{\mathrm{a}}$ & 0.20 \\
\hline
\end{tabular}

Note: FPPW is Fermented pineapple peel waste

According to Ahmed et al. (2013), calcium contain in a diet affects egg quality. The egg shell thickness quality of laying hens inclusion of calcium as much as $2.62 \%$ in a diet weaker compared to fed calcium as much as 3.70 to $4.40 \%$ (Jiang et al., 2013). Previous researchers also reported that the use of pineapple peel flour as much as $8 \%$ in a diet of duck did not affect egg quality (Muharlien et al., 2011).

The increasing use of the FPPW level in laying hens diet with increasing of bromelain concentration and their proteolytic activity in this experiment. We predicted diet with FPPW would help protein digestion and absorption in laying hens in the digestive tract. Akit et al. (2019) reported that bromelain enzyme supplementation in broilers could increase protein and fat digestibility, reduced fecal nitrogen content, moreover increase the height of villi small intestine of starter and finisher broilers, it causing an increase the intestine area for nutrient absorption. However, the egg quality obtained from laying hens fed diet with FPPW was equal with egg quality without the administration of FPPW in a diet. It is mean the bromelain activity from FPPW in all levels of FPPW in a diet of laying hens was the same expression in affected protein digestion and absorption in the digestive tract, and the absorption of protein of laying hens was equal with laying hens fed a diet without FPPW. It assumed. This study founded egg shell thickness of laying hens ranged from 0.43 to $0.45 \mathrm{~mm}$. The results of this study are not much different from those reported by Lien et al. (2012), the use of bromelain enzyme in the diet of laying hens obtained egg shell thickness of 0.39 to $0.43 \mathrm{~mm}$. Laying hens fed bromelain enzyme obtained egg shell thickness of 0.39 to $0.41 \mathrm{~mm}$ (Yenice et al., 2019.

The use of FPPW up to the $20 \%$ level in the diet of laying hens does not interfere with the haugh unit value. Haugh unit was determined by the relationship between high and weight of albumin, haugh unit is values that indicate the quality of the egg. Haugh unit and albumen related to each other to determine egg quality, the egg quality of the inner will have a better egg freshness if accompanied by high of the haugh unit (Wu et al., 2005). The average 
of haugh unit in the study range from 93.2 to 98.0. This value is higher than reported by Vidal et al. (2013), the haugh unit value of laying hens obtained was 82.87 to 86.43 .

In this study, the use of FPPW in the diet of laying hens at all treatments has not been able to reduce egg yolk fat content. We predict that the content of the bromelain enzyme in FPPW is still low, so it has no significant effect on reducing egg yolk fat. However, some researchers have reported that the use of pineapple as poultry feed ingredients can reduce egg yolk fat. The use of $8 \%$ pineapple flour on duck was able to reduce egg yolk fat of 38.68 to $31.36 \%$ (Muharlien et al., 2011). Furthermore, provision of fermented pineapple peel as much as $20 \%$ in the diet of broiler able to decrease of abdominal fat (Mandey et al., 2017). Information about the ability of the bromelain enzyme to reduce egg yolk fat is still limited, and it is still developing.

There was an effect highly significant $(\mathrm{P}<0.01)$ on egg yolk color among the

\section{ACKNOWLEDGMENTS}

This study was funded by a third-year Universitas Andalas professor assembly council grant. Thank you for the Rector of Universitas Andalas and the LPPM of Universitas Andalas for funding and facilitating this research.

\section{REFERENCES}

ADRIZAL.; MAHATA, M.E.; HERYANDI, Y.; AMIZAR, R. Evaluation of pineapple (Ananas Comosus (L.) Merr) waste fermentedusing different local microorganism solutions as poultry feed. Pakistan Journal of Nutrition, v.16, n.2, p. 84-89, 2017. dietary treatments (Table 2). The higher the level of FPPW in a diet of laying hens, the brighter the egg yolk color. Caused by carotenoid contain in FPPW, which affects the brightness level of the egg yolk color. Significantly the egg yolk color increases with the inclusion of carotene to the diet of laying hens (Kotrbacek et al., 2013). According to Nirmalaratne et al. (2012), feed consumed by chickens significantly affects the carotenoid content in egg yolk color. The egg yolk pigment absorbed physiologically and absorbed in internal digestive organs, furthermore, it will spread to target organs that requiring (Sahara, 2010). The total carotenoid content in pineapple is 497 $\mu \mathrm{g} / 100 \mathrm{~g}$, and vitamin $\mathrm{C}$ content of 38.3 $\mathrm{mg} / 100 \mathrm{~g}$ (Ellong et al., 2015). In conclusion, fermented pineapple peel waste could be used in laying hens diet reach $20 \%$ without negative effect on egg yolk fat, haugh unit, egg shell thickness, and egg shell strength, and it increased egg yolk color from 8.49 to 9.41 .

AHMED, N.M.; ATTI, K.A.A.; ELAMIN, K.M.; DAFALLA, K.Y.; MALIK, H.E.E.; DOUSA, B.M. Effect of dietary calcium sources on laying hens performance and egg quality. Journal of Animal Production Advances, v.3, n.7, p. 226-231, 2013.

AKIT, H.; ZAINUDIN, N.N.M.N.; WAHID, N.A.A.; ZAKARIA, S.N.; FOO, H.L.; LOH, T.C. Dietary bromelain improves nutrient digestibility, digesta viscosity and intestinal villus height as well as reduces intestinal E. coli population of broiler chickens. Malaysian Society of Animal Production, v.22, n1, p. 1-16, 2019. 
AOAC. Official Methods of Analysis of AOAC International 18th edition. Vol II. Published by AOAC International. Gaithersburg, Maryland USA, 2005.

AYDIN, R.; KARAMAN, M.; CICEK, T.; YARDIBI, H. Black cumin (Nigella sativa $\mathrm{L}$.) supplementation into the diet of the laying hen positively influences egg yield parameters, shell quality, and decrease egg cholesterol. Poultry

Science, v.87, n.12, p. 2590-2595, 2008.

CAMPOS, D.A., RIBEIRO, T.B., TEIXEIRA, J.A., PASTRANA, L., PINTADO, M.M. Integral valorization of pineapple (ananas comosus 1.) byproducts through a green chemistry approach towards added value ingredients. Food, v.9, n.60, p.1-22, 2020 .

ELLONG, E.N.; BILLARD, C.; ADENET, S.; ROCHEFORT, K. Polyphenols, carotenoids, vitamin C content in tropical fruits and vegetables and impact of processing methods.

Food and Nutrition Sciences, v.6, p. 299-313, 2015.

HAUGH, R.R. The Haugh unit for measuring egg quality. United States Egg and Poultry Magazine, v.43: p.522-555, 1937.

INDONESIA CENTRAL BUREAU OF STATISTIC. Statistik tanaman buahbua- han dan sayuran tahunan Indonesia 2017. ISSN: 2088-8406. No. Publikasi: 05120.1807. Katalog: 5205010, 2017.

INDONESIA CENTRAL BUREAU OF STATISTIC. 2018. Statistik tanaman buah-bua- han dan sayuran tahunan Indonesia 2018. ISSN: 2088-8406. No. Publikasi: 05120.1901. Katalogg: 5205010, 2018.

JIANG, S.; CUI, L.; SHI C.; KE, X.; LUO, J.; HOU, J. Effects of dietary energy and calcium levels on performance, engshell quality and bone metabolism in hens. The Veterinary Journal, v.198, n.1, p. 252-258, 2013.

KOTRBACEK, V.; SKRIVAN, M.; KOPECKY, J.; PENKAVA, O.; HUDECKOVA, P.; UHRIKOVA, I.; DOUBEK, J. Retention of carotenoids in egg yolks of laying hens supplemented with heterotropic Chlorella. Czech Journal of Animal Science, v.58, n.5, p. 193-200, 2013.

LABORATORY ANALYSIS OF FEED INDUSTRY TECHNOLOGY, FACULTY OF ANIMAL SCIENCE, UNIVERSITAS ANDALAS (2017).

LIEN, T.F.; CHENG, Y.H.; WU, C.P. Effects of supplemental bromelain on egg production and quality, serum and liver traits of laying hens. Journal of Animal Science Advances, v.2, n.4, p. 386-391, 2012.

MAHATA, M.E. Processing pineapple peel waste with local microorganism for poultry feed. Scientic oration inaguration of profesor, Universitas Andalas, Padang, Indonesia, 2019.

MAHATA, M.E.; HERYANDI, Y.; ADRIZAL. Fermentasi limbah kulit nenas (Ananas Comosus. (L.) Merr) Dengan Mikroorganisme Lokal (MOL) untuk pakan unggas. Laporan Penelitian Hibah Riset Guru Besar Universitas Andalas Tahun Pertama, Padang, 2016. 
MANDEY, J.S.; TULUNG, B.; LEKE, J.R.; SONDAKH, B.F.J. Performance and carcass quality of broiler chickens fed diet containing pineapple waste meal fermented by "ragi tape". IOP Conf. Series: Earth and

Environmental Science1213042, 012042, 2017.

MANOSROI, A.; CHANKHAMPAN, C.; PATTAMAPUN, K.; MANOSROI, W.; MANOSROI, J. Antioxidant and Gelatinolytic Activities of Papain from Papaya Latex and Bromelain from Pineapple Fruits. Chiang Mai Journal of Science, v.41, n.3, p. 635-648, 2014.

MUHARLIEN.; VITRA.; NATSIR, M.H. The Effect of Addition Pineapple Peel Meal (Ananas comosus (L) Merr) in Diet on Total Egg and Egg Duck Quality. Journal of Science and Livestock Product Technology, v.6, n.2, p. 15-20, 2011.

NIRMALARATNE, C.; LOPES-LUTZ, D.; SCHIEBER, A.; WU, J. Effect of domestic cooking methods on egg yolk xanthophylls. Journal of Agricultural and Food Chemistry, v.60, n.51, p. 12547-12552, 2012.

SAHARA, E. Penggunaan kepala udang sebagai sumber pigmen dan kitin dalam pakan ternak. Jurnal Agribisnis dan Industri Peternakan, v.1, n.1, p. 3135, 2011.

STELL, R.G.D.; TORRIE, J.H. Statistical principles and procedures of a biometric approach. 2nd edition, translated by Bambang Sumatri. PT. Gramedia Pustaka Utama, Jakarta, Indonesia, 1995.
SWAN, R.; NAGENDRAN, S.

Protease: An enzyme with multiple industrial applications. World Journal of Pharmacy and Pharmaceutical Sciences, v.3, n.6, p. 568-579, 2014.

VIDAL, T.F.; PEREIRA, A.L.F.; ABREU, V.K.G.; FREITAS, E.; NETO, M.A.S.; ZAPATA, J.F.F. Egg quality and yolk lipid composition of laying hens fed diets containing cashew nut meal. Food Science and Technology, v.33, n.1, p. 172-179, 2013.

WU, H.; ITO, K.; SHIMOI, H. Identification and characterization of a novel biotin biosynthesis gene in Saccharomyces cerevisiae. Applied and Environmental Microbiology, v.1, n.11, p. 6845-6855, 2005.

YENICE, G.; ISKENDER, H. Dokumacioglu, E.; Kaynar, O.; Kaya, A.; Hayirli, A.; Sezmis, G. Dietary bromelain supplementation for improving laying performance, egg quality and antioxidant status.

European Poultry Science, v.83, p. 116, 2019. 